\title{
Chronic Myelomonocytic Leukemia-2
}

National Cancer Institute

\section{Source}

National Cancer Institute. Chronic Myelomonocytic Leukemia-2. NCI Thesaurus. Code C36062.

A chronic myelomonocytic leukemia characterized by the presence of 10-19 percent blasts in the bone marrow and 5-19 percent blasts in the peripheral blood or by the presence of Auer rods regardless of the blasts count. 